\title{
Sources of Holocene variability of oxygen isotopes in paleoclimate archives
}

\author{
A. N. LeGrande and G. A. Schmidt \\ NASA Goddard Institute for Space Studies and Center for Climate Systems Research, Columbia University, 2880 Broadway, \\ New York, NY 10025, USA
}

Received: 6 March 2009 - Published in Clim. Past Discuss.: 23 March 2009

Revised: 30 July 2009 - Accepted: 30 July 2009 - Published: 7 August 2009

\begin{abstract}
Variability in water isotopes has been captured in numerous archives and used to infer past climate changes. Here we examine water isotope variability over the course of the Holocene using the water-isotope enabled, coupled atmosphere-ocean general circulation model, GISS ModelER. Eight Holocene time slices, $\sim 1000$ years apart are simulated and driven by estimated changes in orbital configuration, greenhouse gases, and ice sheet extent. We find that simulated water isotope archives match well with those seen in ice cores, ocean sediment cores, and speleothems. The climate changes associated with the water isotope changes, however, are more complex than simple modern spatial slope interpretations might suggest. In particular, water isotope variability in Asian speleothems is linked to alterations in landward water vapor transport, not local precipitation, and ice sheet changes over North America lead to the masking of temperature signals in Summit, Greenland. Salinity-seawater isotope variability is complicated by inter-ocean basin exchanges of water vapor. Water isotopes do reflect variability in the hydrology, but are better interpreted in terms of regional hydrological cycle changes rather than as indicators of local climate.
\end{abstract}

\section{Introduction}

Water isotopes are important tracers of the hydrologic cycle. In the atmosphere, the oxygen isotopic composition of precipitation, $\delta^{18} \mathrm{O}_{\text {prec }}(\delta$ in per mil units $\equiv-$ Rsample/Rstd $-1 \times 1000$ - refers to the ratio of the sample concentration to a known standard) is a product of the initial composition of $\delta^{18} \mathrm{O}$ in the water vapor of an air parcel and the amount of rain out, evaporation of rainfall,

Correspondence to: A. N. LeGrande

(legrande@giss.nasa.gov) and mixing of that air parcel along its path. It is correlated to surface air temperature at mid to high latitudes and thought to correlate to the amount of precipitation at low latitudes over short time periods seen in modern observations (Araguas-Araguas et al., 2000; Dansgaard, 1964). Long term records of $\delta^{18} \mathrm{O}_{\text {prec }}$ available in ice cores (Jouzel et al., 2007), speleothems (Wang et al., 2008), lake records (von Grafenstein et al., 1999), and tree cellulose (Treydte et al., 2007), provide a way to infer information about climate if appropriate interpretations can be found (Cuffey et al., 1995; Jouzel et al., 2003; Roden et al., 2000; Wang et al., 2001).

Similarly, the oxygen isotopic composition of seawater, $\delta^{18} \mathrm{O}_{\mathrm{sw}}$ is a tracer of circulation and of surface ocean fluxes. In the ocean, $\delta^{18} \mathrm{O}_{\mathrm{sw}}$ is regionally related to salinity since fluxes of freshwater (precipitation and evaporation) affect the concentration of both. Variations in $\delta^{18} \mathrm{O}_{\mathrm{sw}}$ are more complicated than salinity since water isotopes undergo additional fractionation and transport in the atmosphere (Craig and Gordon, 1965).

The $\delta^{18} \mathrm{O}_{\mathrm{sw}}$ is preserved in the calcite shells of marine microfossils such as foraminifera as well as the aragonite skeletons of corals. These ratios are complicated by a temperature dependent fractionation of $-1 \%$ per $5^{\circ} \mathrm{C}$ of $\delta^{18} \mathrm{O}$ (Epstein et al., 1953) and species dependent "vital effects". Past variability in $\delta^{18} \mathrm{O}_{\mathrm{sw}}$ can potentially be reconstructed given paired measurements of $\delta^{18} \mathrm{O}$ in calcite and an independent temperature proxy (e.g. $\mathrm{Mg} / \mathrm{Ca}$ in calcite), giving insight into the past hydrologic cycle (Schmidt et al., 2004).

Alterations in orbital configuration have long been postured as the primary driver of climate change over the last 10000 years. Holocene perihelion changes enhanced Northern Hemisphere seasonality, with the maximum changes occurring in the early Holocene. In the tropics, the monsoon was likely more intense in the early Holocene, with intensity diminishing through the modern (Maher, 2008).

Published by Copernicus Publications on behalf of the European Geosciences Union. 
The key to interpreting the signals in paleoclimate records is an estimate of the temporal gradient - the relative covariability of climate and $\delta^{18} \mathrm{O}$ in a set location over time. Often people have applied modern spatial gradients - the relative co-variability of climate and $\delta^{18} \mathrm{O}$ over a region - but these need not be the same as temporal gradients. Further, temporal gradients over different timescales or kind of climate change may also be variable (Schmidt et al., 2007).

In the ocean, variability in $\delta^{18} \mathrm{O}_{\mathrm{sw}}$ has been used to infer past salinity variability given the modern (regional) relationship between $\delta^{18} \mathrm{O}_{\text {sw }}$ and salinity (Schmidt et al., 2004; Stott et al., 2004). These reconstructions assume that the modern regional (spatial) relationship - which is the regression of the $\delta^{18} \mathrm{O}_{\mathrm{sw}}$ to salinity relationship over a region - was valid over a range of timescales at a finite point in space; i.e. the reconstructions of salinity assume that the temporal relationship between the two is equivalent to the spatial relationship. Since the hydrologic cycle itself - including atmospheric variations in $\delta^{18} \mathrm{O}$ - is impacted by climate, this assumption has been called into question (Schmidt, 1999). During times of climate change, it is possible that the relationship of $\delta^{18} \mathrm{O}_{\mathrm{sw}}$ to salinity and $\delta^{18} \mathrm{O}_{\text {prec }}$ to precipitation/temperature have also changed.

Given these concerns, a thorough examination of the spatial relationships derived from the modern distribution of water isotopes and climate and their connection to the temporal relationships is necessary. For instance, in Greenland, paired measurements of water isotopes and borehole temperatures establish that the spatial ratio between temperature and $\delta^{18} \mathrm{O}_{\text {prec }}$ regionally are roughly twice the temporal ratio between the two (Cuffey et al., 1995; Masson-Delmotte et al., 2006; Werner et al., 2000). Ice records from Antarctica at present do not seem to have the same complicating factor (Jouzel et al., 2003; Masson-Delmotte et al., 2008), though recent work suggests that the relationship may not be linear (Sime et al., 2008). However, the potential for such divergence in temporal and spatial ratios suggests that further, site and proxy-specific work is required.

Future climate, given a business as usual scenario, will likely be significantly warmer than today. However, climate models have been thoroughly tested only on the range of climate variability over the last 100 years. Therefore, in order to be evaluated for changes on par to those projected, models need to be tested over the much greater range of variability inferred from the paleoclimate record. The early to mid-Holocene Northern hemisphere Holocene climate has traditionally been seen as a good target for these purposes. Specifically, mid-Holocene (6000 BP) climate changes are regularly simulated as part of model-data intercomparison projects (e.g. PMIP2: Braconnot et al., 2007; Masson-Delmotte et al., 2006). These comparisons are useful in highlighting model skills and deficiencies. The key questions in these comparisons are related to the sensitivity of the tropical and sub-tropical rainfall regimes and the sensitivity of the meridional overturning circulation to the progressive melting of ice sheets, particularly in the Early Holocene, during the last phases of the deglaciation.

Here we explore the variability of the $\delta^{18} \mathrm{O}$ over the Holocene (last 10000 years) using a fully coupled atmosphere-ocean general circulation model (GCM) that explicitly tracks water isotopes. We quantify the impact of orbital variations, (small) greenhouse gas variations, and ice sheet variation in order to (1) examine the amount of variability of the proxy records compared to climate, (2) assess the skill of the model in reproducing the Holocene climate variability, and (3) suggest improvements to the interpretation of isotopic data from this period.

\section{Methods and model description}

GISS ModelE-R (Goddard Institute for Space Studies ModelE-R) is a fully coupled atmosphere/ocean GCM. The experiments here use the M20 version of ModelE whose horizontal resolution is $4^{\circ} \times 5^{\circ}$, with a 20 vertical layer atmosphere up to $0.1 \mathrm{hPa}$ height (Schmidt et al., 2006) coupled to the 13-layer Russell Ocean model at the same horizontal resolution (Hansen et al., 2007). Atmospheric advection uses the quadratic upstream scheme, with 9 moments advected in addition to mean quantities, significantly enhancing the effective tracer resolution (to $\sim 1.3^{\circ} \times \sim 1.6^{\circ}$ ). The ocean model is non-Boussinesq, mass conserving, and has a full free surface. Freshwater is treated in a "natural" way; i.e. the addition of freshwater increases the free surface and reduces salinity purely through dilution. No equivalent salt fluxes or flux adjustments are used, allowing for the prognostic calculation of water isotope to salinity relationships. All boundary conditions and atmospheric composition in the control case are appropriate to the pre-industrial period (circa 1880).

Water tracers $\left({ }^{1} \mathrm{H}_{2}^{16} \mathrm{O}\right.$, "normal" water; ${ }^{2} \mathrm{H}^{1} \mathrm{H}^{16} \mathrm{O}, \delta \mathrm{D}$; ${ }^{1} \mathrm{H}_{2}^{18} \mathrm{O}, \delta^{18} \mathrm{O}$; where $\delta$ in permil $(\% o) \equiv\left[\left(R_{\text {std }} / R_{\text {smow }}\right)-1\right]$ $X$ 1000) are included in the atmosphere, land surface, sea ice, and ocean and are tracked through all stages of the hydrologic cycle (Schmidt et al., 2007). These isotopes are advected like water through the model, but at each phase change, an appropriate fractionation is performed (Schmidt et al., 2005).

Eight "time slice" experiments were performed, giving roughly 1000 year temporal coverage across the Holocene (Table 1). In each, greenhouse gas concentrations were adjusted based on ice core reconstructions (Brook et al., 2000; Indermuhle et al., 1999; Sowers et al., 2003), and seasonal insolation was changed as a function of changing orbital parameters (Berger and Loutre, 1991). For the 9 kya (kiloyears ago) experiment, a remnant Laurentide ice sheet was included (Licciardi et al., 1998, Fig. 1), and mean ocean water salinity and $\delta^{18} \mathrm{O}$ adjusted to account for ice volume ( $35 \mathrm{psu},+0.33 \%$ o equivalent to $\sim 35$ meters of sea level) changes (Fairbanks, 1989). Each experiment was run 500 


\section{Topography Difference for LIS (meters) at 9 kya}

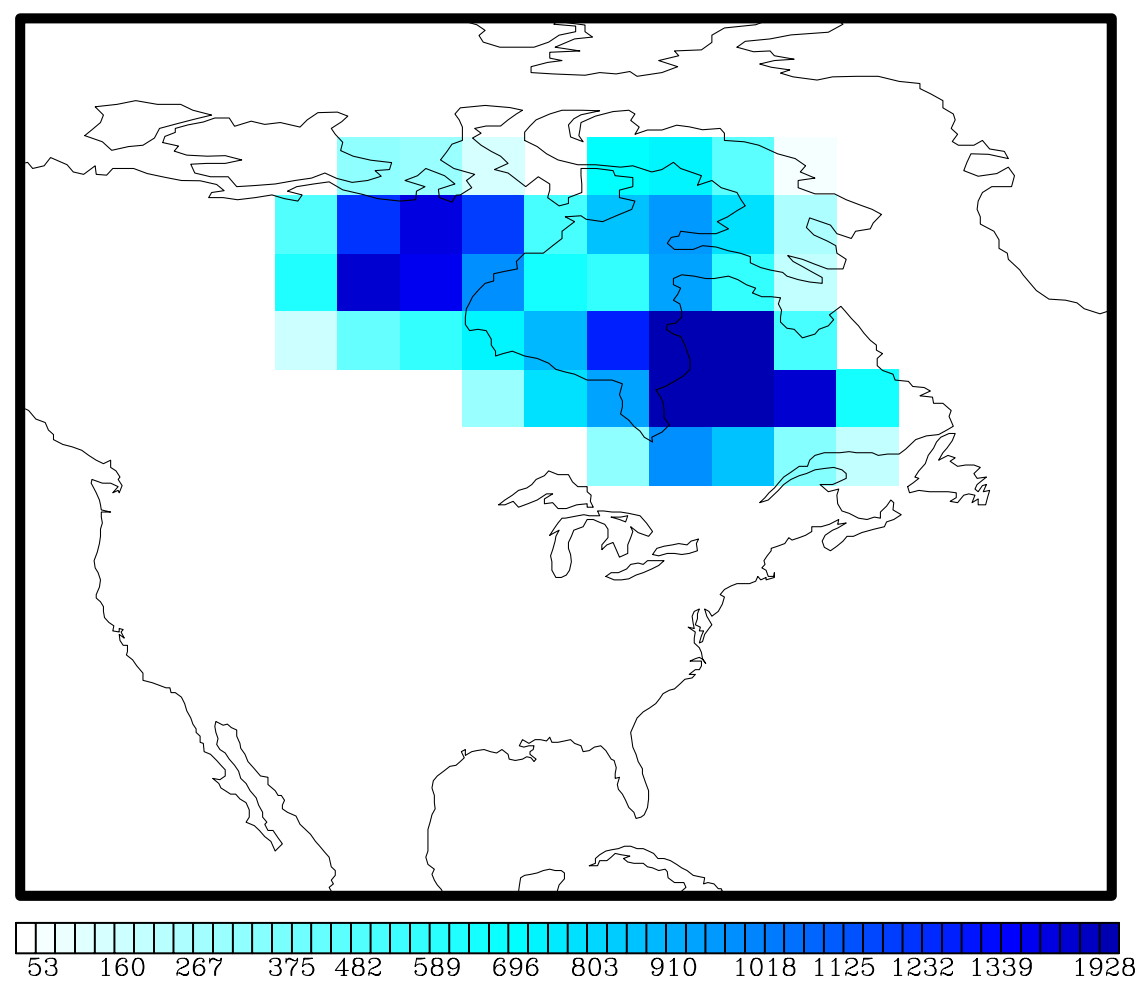

Fig. 1. Topography anomaly at 9 kya showing the remnant Laurentide Ice Sheet. Adapted from Licciardi et al. (1998).

Table 1. Changes in boundary conditions for Holocene simulations include changes to greenhouse gases (Indermuhle et al., 1999) and perihelion in Julian days (Berger and Loutre, 1991) for all simulations. The 9 kya simulation includes the Laurentide Ice Sheet (Licciardi et al., 1998), and the correspondent adjustment to mean ocean salinity to $35 \mathrm{psu}$ and $\delta^{18} \mathrm{O}_{\mathrm{sw}}$ to $+0.33 \%$ (Fairbanks, 1989).

\begin{tabular}{rrrrrr}
\hline Time (kya) & $\mathrm{CO}_{2}$ (fraction) & $\mathrm{CH}_{4}$ (fraction) & $\mathrm{N}_{2} \mathrm{O}$ (fraction) & Perihelion & Ice \\
\hline 0 & 1 & 1 & 1 & 2.7 & No \\
1 & .98 & .87 & .94 & 349.6 & No \\
2 & .98 & .81 & 1 & 332.3 & No \\
3 & .97 & .80 & .95 & 314.9 & No \\
4 & .96 & .77 & .94 & 297.4 & No \\
5 & .95 & .71 & .94 & 279.9 & No \\
6 & .95 & .71 & .82 & 262.4 & No \\
9 & .93 & .83 & .89 & 210.4 & Yes \\
\hline
\end{tabular}

years, reaching quasi-equilibrium, and the last 100 years of the experiments are presented here.

The ice sheet module used here is very simplified. Eustatic sea level remains fixed, with net accumulation over the ice sheets partitioned into northern and southern hemisphere amounts then returned to the oceans through "calving" of ice in the upper $200 \mathrm{~m}$ of the water column at observed locations around Greenland and Antarctica and inferred locations around the Laurentide (9 kya case only). The isotopic composition of the water is determined by the average decadal isotopic composition of the convergent water flux on the surface of the ice sheet. The salinity of the ice bergs is zero and the temperature is set to conserve total enthalpy.

\section{Results}

To facilitate comparisons, changes are reported in past anomalies compared to present (0kya, pre-Industrial) simulations. Thus, statements about cooler temperatures or less rainfall refer to cooler temperatures or less rainfall in the past relative to the 0 kya simulation. 

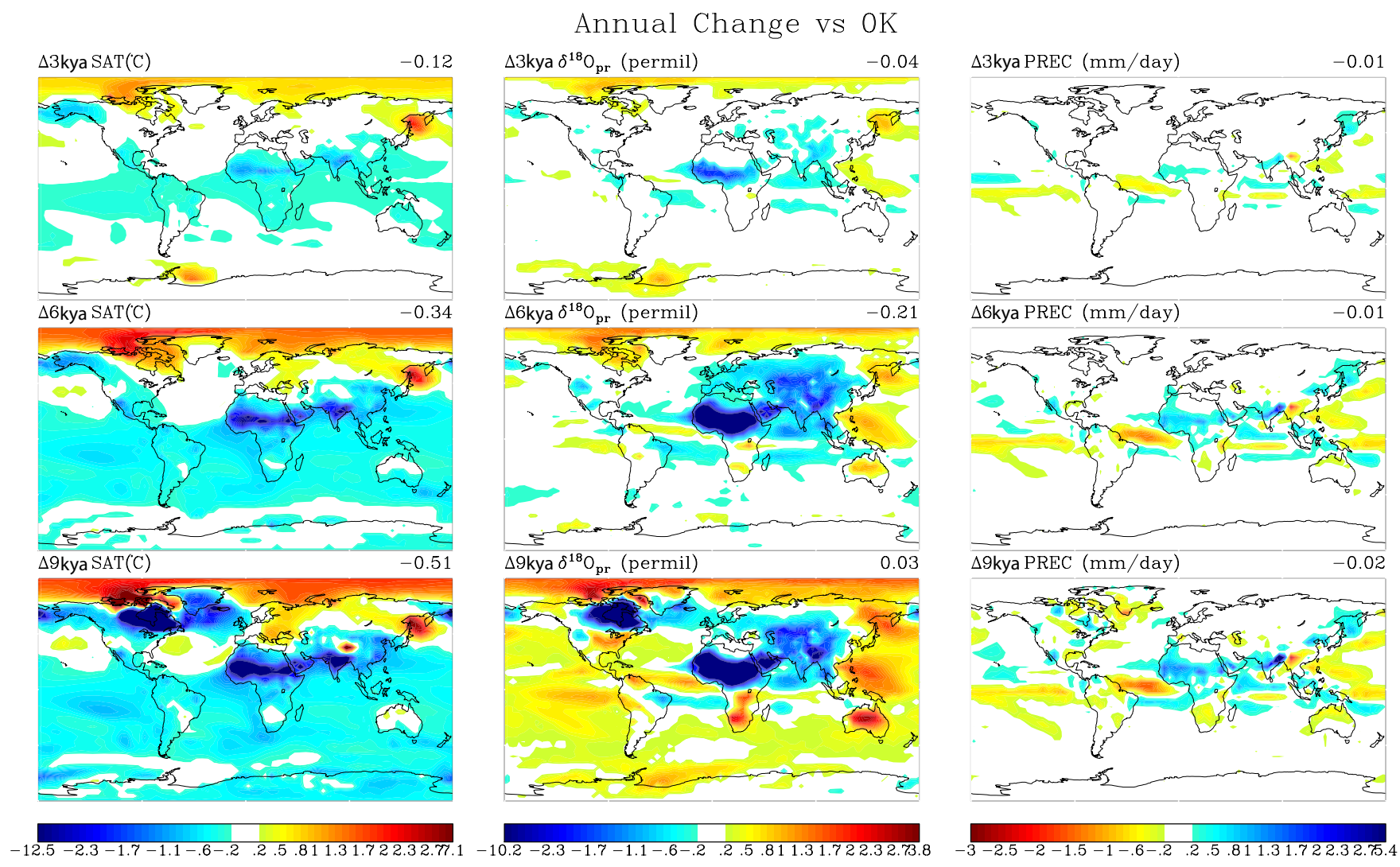

Fig. 2. Anomaly atmosphere climatology at $3 \mathrm{kya}$ (top), $6 \mathrm{kya}$ (middle), and $9 \mathrm{kya}$ (bottom) for $\mathrm{SAT}$ (left), $\delta^{18} \mathrm{O}_{\text {prec }}$ (middle), and precipitation (right). Values reported are greater than $99 \%$ significance (student's t-test) given the decadal variability about the 100 -year mean.

\subsection{Large scale climate changes}

Northern Hemisphere extra-tropical insolation was significantly enhanced in summer, and somewhat reduced in winter; in the early Holocene ( $\mathrm{EH} \equiv 9$ kya simulation) boreal summers received up to $60 \mathrm{~W} / \mathrm{m}^{2}$ greater insolation, while boreal winter insolation was somewhat reduced $\left(\sim 15 \mathrm{~W} / \mathrm{m}^{2}\right)$. Compared to the pre-industrial, Holocene greenhouse gas forcing was negative, $\sim-0.7 \mathrm{~W} / \mathrm{m}^{2}$ in the $\mathrm{EH}$ to midHolocene ( $\mathrm{MH} \equiv 6$ kya simulation). Cumulatively, these forcings caused annual mean warming in the Northern Hemisphere, up to $2-3^{\circ} \mathrm{C}$, with cooling the Southern Hemisphere around $1^{\circ} \mathrm{C}$ (annual average, Fig. 2) in the mid-Holocene. In general, anomalies have similar patterns, but greater magnitudes in the early Holocene compared to the $\mathrm{MH}$ compared to the Late Holocene ( $\mathrm{LH} \equiv 3$ kya simulation).

Simulated summer sea ice decreases by $\sim 5 \%$ in the Arctic in the early Holocene; though changes in sea ice may be underestimated in ModelE- $\mathrm{R}$ since the sea ice in this version of the model is relatively (and possibly erroneously) insensitive to warming Arctic temperatures (Stroeve et al., 2007). Early Holocene boreal summer temperature anomalies reach $4^{\circ} \mathrm{C}$ in interior regions of Eurasia as well as the Canadian Arctic (Fig. 3). Greenland Surface Air Temperatures (SATs) are simulated to be $1-2^{\circ} \mathrm{C}$ warmer in summer. Boreal winter SATs are largely cooler over land, but warmer over the Arctic Ocean resulting from a persistent reduction in sea ice, with anomalies approximately twice the magnitude of those in summer. Boreal summer land-sea SAT contrast is enhanced in all Holocene simulations compared to the modern, with the greatest contrast in the Early to Mid-Holocene simulations. These changes are consistent with climate reconstructions of North America and Europe showing maximum summer warmth attained 7000-9000 years ago, and decreasing temperatures into the pre-Industrial (Wanner et al., 2008).

In the early Holocene, the (remnant) Laurentide ice sheet (LIS - inferred to be $3000 \mathrm{~m}$ thick in places, though isostatic compensation makes the surface height anomaly relative to modern smaller by $\sim 2 / 3$, Licciardi et al., 1998) yields local cooling of up to $12^{\circ} \mathrm{C}$. Additionally, the orographic forcing of the remnant ice sheet itself causes a southward deflection of the atmospheric jets, yielding further cooling downstream over Greenland and eastward into the western GIN (Greenland/Iceland/Norwegian) Seas (Carlson et al., 2008), consistent with simulations from Earth Models of Intermediate Complexity (Renssen et al., 2009). 


\section{Early Holocene (9 kya) Seasonal Anomalies}
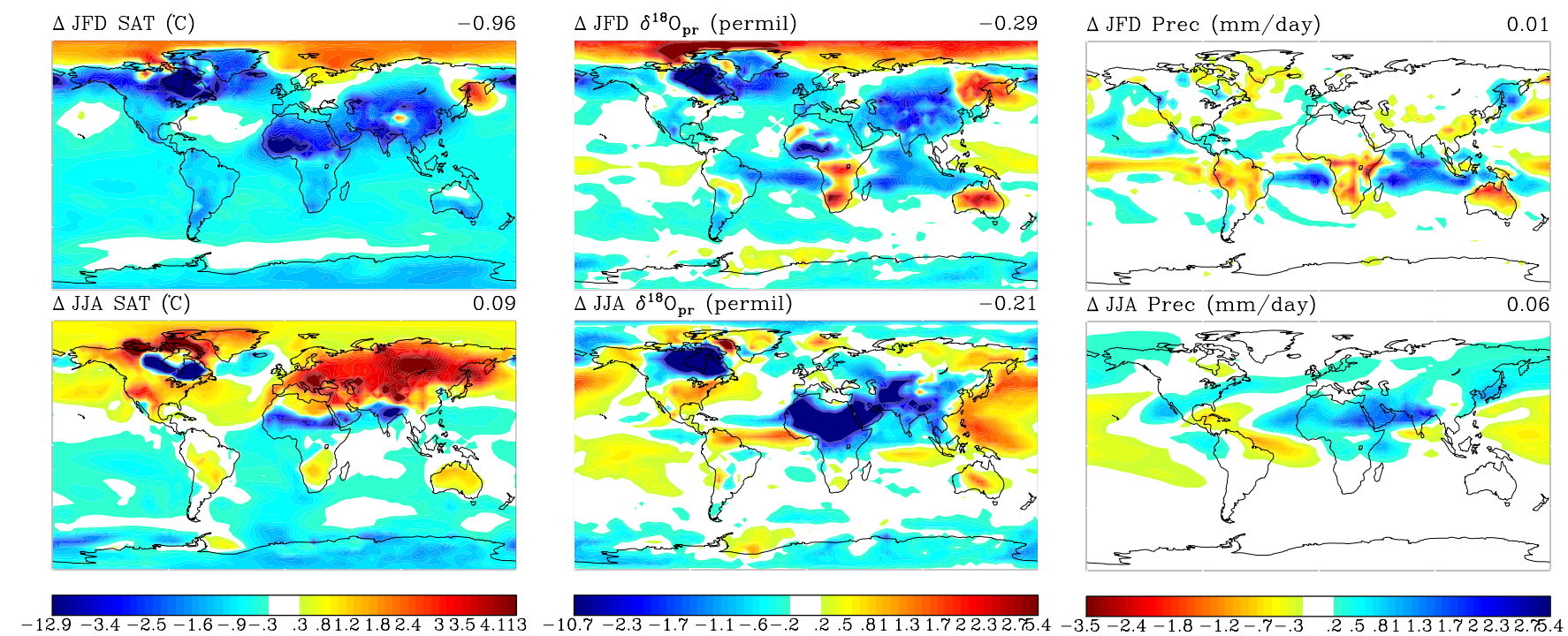

Fig. 3. Seasonal atmospheric changes at 9 kya boreal winter (bottom) and boreal summer (top) for SAT (left), $\delta^{18} \mathrm{O}_{\text {prec }}(\mathrm{middle})$, and precipitation (right).

Surface solar forcing of $\sim 20 \mathrm{~W} / \mathrm{m}^{2}$ (greater than today) over the remnant Laurentide ice sheet (LIS) induces a significant ice budget imbalance in the LIS in our simulation, which leads to a fresher Labrador Sea (Carlson et al., 2008). LIS glacial melt water is specified to be fresh with $\delta^{18} \mathrm{O}_{\text {ice }}$ the average of $\delta^{18} \mathrm{O}_{\text {prec }}$ over northern hemisphere land ice. LIS melt enters the ocean as "ice bergs" in the upper $200 \mathrm{~m}$ of the water column, causing alterations to the upper ocean density structure of the Labrador Sea, suppressing the formation of deep water. This leads to a reduction in the early Holocene simulated North Atlantic Deep Water (NADW: defined as the magnitude of the ocean overturning stream-function at $48^{\circ} \mathrm{N}, 900 \mathrm{~m}$ ) of $\sim 23 \%$.

This suppression of deepwater formation in the Northwestern Atlantic may have been an important preconditioning of ocean circulation changes in the early Holocene. Other simulations have shown that the lack of Labrador Deep Sea Water allows for a larger climate response to sudden freshwater forcing (LeGrande and Schmidt, 2008). The size and magnitude $8.2 \mathrm{kyr}$ event (largest northern Hemisphere "cool" anomaly in Greenland ice core records, Thomas et al., 2007) could well have been influenced by the earlier melting of the LIS and related suppression of Labrador Deep Sea Water.

In all other simulations, simulated NADW is steady $(\sim 22 \pm 1 \mathrm{~Sv}$ ), consistent with proxy indicators (McManus et al., 2004). This transition in NADW production as the LIS disappears is consistent with proxy indications that deep water production in the Labrador Sea was absent until around 7000BP (Hillaire-Marcel et al., 2001). The inferred change at that time is postulated to have been due to the deglaciation that was still ongoing through around 6500BP, when eustatic sea level reached near-modern levels (Carlson et al., 2007). In the Early Holocene, the lack of Labrador Deep Sea Water production yields regionally cooler $\left(1-2^{\circ} \mathrm{C}\right)$ winter SAT. There is also a reduction in precipitation over the Labrador Sea convection areas.

Sea surface temperatures (SST) in the Northern Hemisphere are warmer in the earlier periods. Generally, this pattern is most prominent in the Early Holocene, with decreases in insolation and Northern Hemisphere temperature into the modern. Lower greenhouse gases yield slight SST cooling in the tropics and Southern Hemisphere. As a result, SST gradients are altered, and the simulated ITCZ (Inter-tropical Convergence Zone) shifts northward (Figs. 2 and 3) in the Holocene, consistent with proxy estimates (Haug et al., 2001; Pearman et al., 2008).

This alteration has important consequences for inter-ocean basin salinity gradients. In particular, water vapor transport across the Isthmus of Panama, a phenomenon important in maintaining the modern Atlantic to Pacific 1 psu salinity gradient, reduces by $\sim 5 \%$ in the Mid-Holocene (Fig. 4).

Latent heat and cloudiness changes associated with the simulated ITCZ movement yield cooling over West Africa and eastward into the Middle East. Precipitation changes over Asia are generally small with both positive and negative 

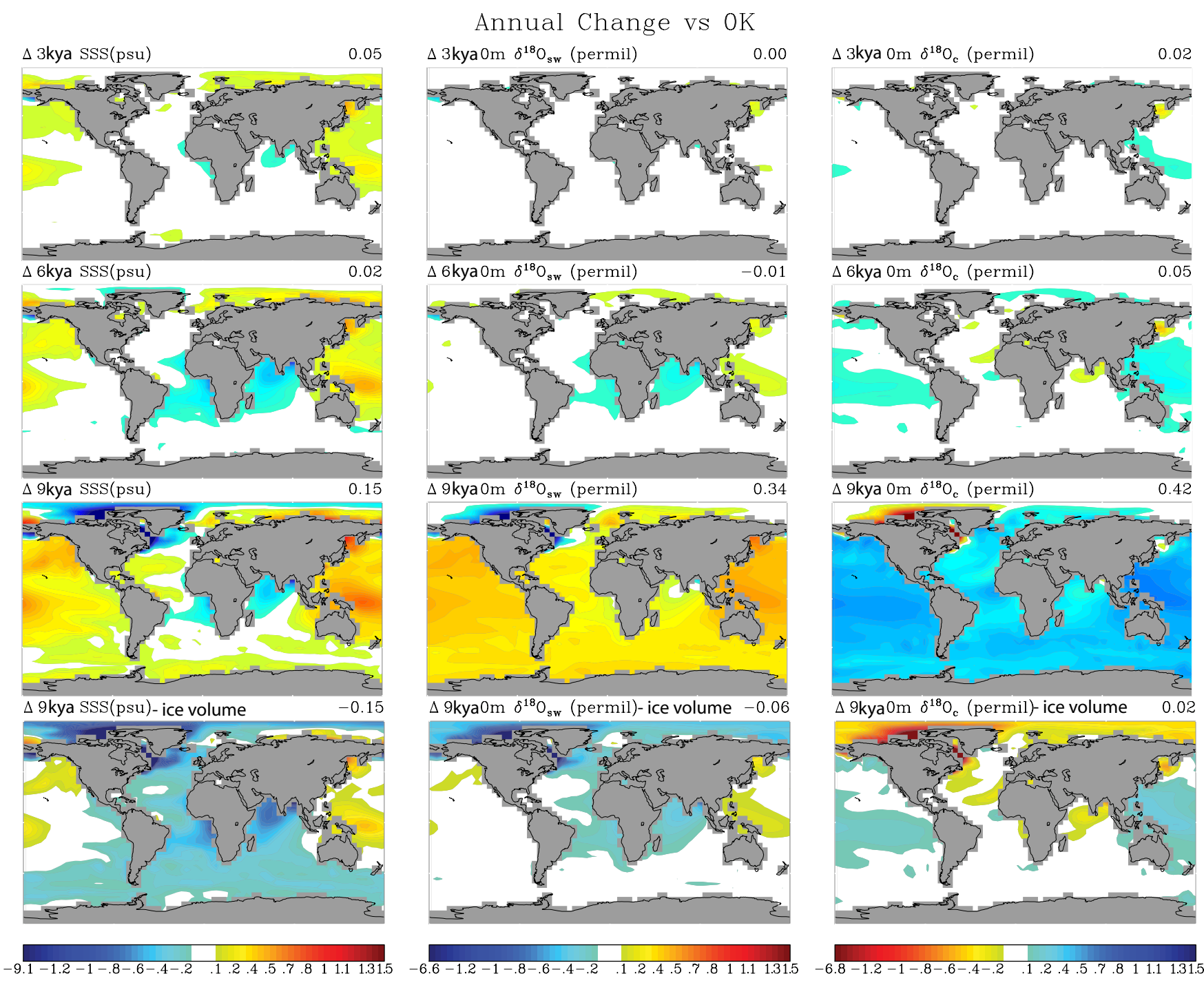

Fig. 4. Anomaly ocean climatology at 3 kya (top), 6 kya (upper middle), 9 kya (lower middle), and 9 kya less ice volume effects (bottom) for SSS (left), surface $\delta^{18} \mathrm{O}_{\text {sw }}$ (middle), and surface $\delta^{18} \mathrm{O}_{\text {calcite }}$ (right). Values reported are greater than $99 \%$ significance (student's t-test) given the decadal variability about the 100 -year mean.

anomalies, with the zero anomaly line centered over the Himalayas. Precipitation over the Western Tropical Pacific warm pool, the Western Atlantic into the Caribbean, and south-east Asia is reduced, particularly in boreal winter. Boreal summer precipitation increases broadly over West Africa eastward into India (Fig. 3).

\subsection{Isotopic changes}

Warmer temperatures and reductions in Arctic sea ice across the Arctic and the Northern Hemisphere are generally associated with heavier $\delta^{18} \mathrm{O}_{\text {prec }}$ in 6 kya through 1 kya simulations relative to modern (Fig. 2). Isotopic anomalies in the early Holocene, however, are more complex and complicated by the impacts of the remnant ice. The negative mass balance of the LIS reduces NADW which yields cooler temperatures associated with lighter $\delta^{18} \mathrm{O}_{\text {prec }}$. In addition, the melt water is highly depleted in $\delta^{18} \mathrm{O}$ reinforcing lighter regional $\delta^{18} \mathrm{O}_{\text {prec }}$ values near the LIS. These competing effects in the early Holocene yield a front between negative and positive $\delta^{18} \mathrm{O}_{\text {prec }}$ anomalies (Fig. 3). The simulation of this front will likely not precisely replicate the actual situation in the early Holocene; however, it does suggest that such a pattern may have existed in the past.

Topographic changes further complicate Greenland $\delta^{18} \mathrm{O}_{\text {prec }}$ changes in the early Holocene. The existence of the LIS forces atmospheric jets to divert southward (Carlson et al., 2008). In the absence of North American ice sheets, 


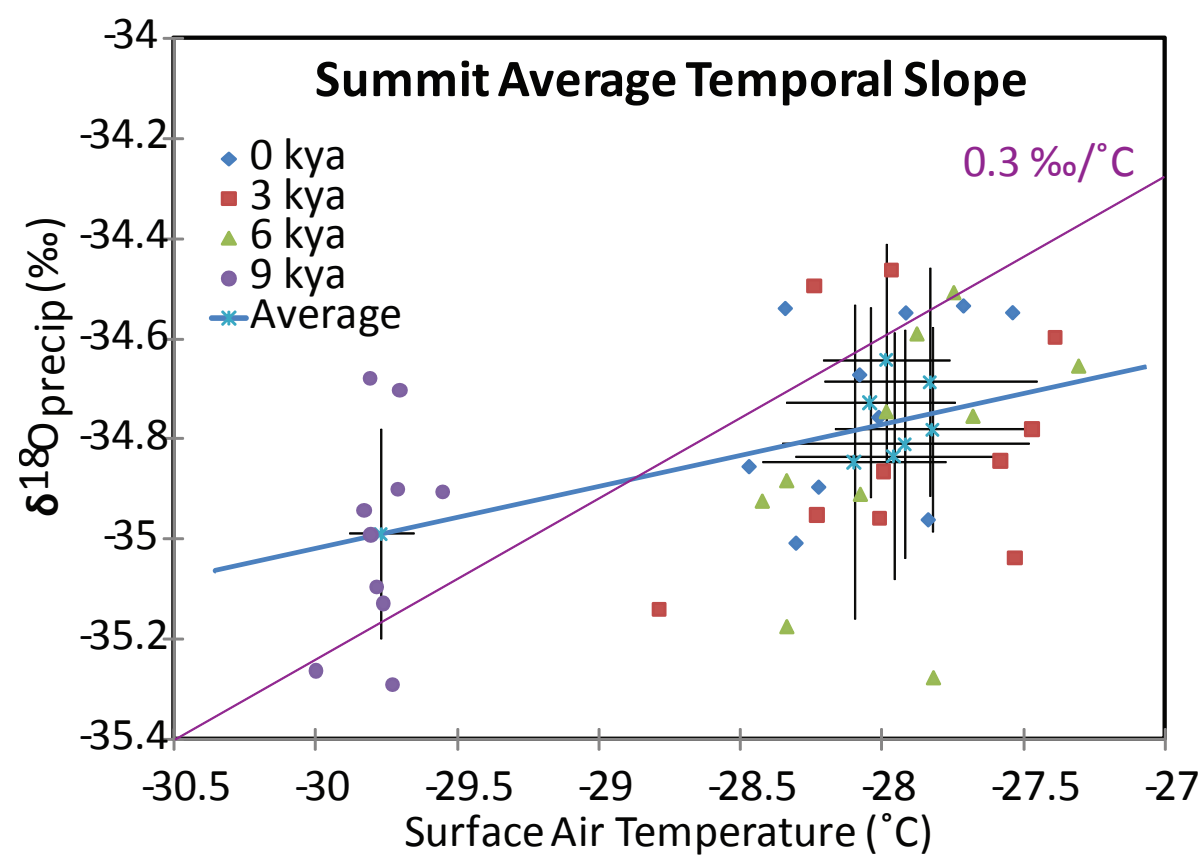

Fig. 5. Simulated annually averaged $\delta^{18}$ Oprec from Summit, Greenland for all eight time slices ( $1 \sigma$ variation in the decadal mean, black bars, about the century average, blue asterisk) are plotted against surface air temperature $\left({ }^{\circ} \mathrm{C}\right)$. A previously suggested relationship between the two, $0.3 \%$ o ${ }^{\circ} \mathrm{C}$ (Cuffey et al., 1995) is plotted in purple, the simulated Early Holocene to modern trend is plotted in light blue.

water vapor from Pacific supplies a significant proportion of boreal summer moisture to Summit $(\sim 30 \%$ in this version of ModelE-R). In the early Holocene, there is a relatively greater amount of rainfall with more local sources, such as the Labrador and Greenland Seas. These shorter pathways result in an air mass that retains a greater amount of heavier isotope in the water vapor once it reaches Greenland. Heavier $\delta^{18} \mathrm{O}_{\text {prec }}$ values can thus occur even if temperatures were held constant. In the simulated early Holocene, Summit temperatures are cooler, but no significant $\delta^{18} \mathrm{O}_{\text {prec }}$ changes are observed, largely as a result of the shorter pathway for water vapor from the ocean to Summit. Just north of Summit, $\delta^{18} \mathrm{O}_{\text {prec }}$ values are higher. Fundamentally, however, the simulated front between positive and negative anomalies in temperature differs to that in $\delta^{18} \mathrm{O}_{\text {prec }}$ because of the orographic changes in the early Holocene. Where this mismatch occurs, standard high latitude temperature to $\delta^{18} \mathrm{O}_{\text {prec }}$ relationships break down. Consistent with these simulations are observational evidence at Summit, Greenland that shows little to no changes in $\delta^{18} \mathrm{O}_{\text {prec }}$ over the course of the Holocene at GISP (Alley et al., 1997), and slightly higher $\delta^{18} \mathrm{O}_{\text {prec }}$ values in the early Holocene for GRIP and North-GRIP (Masson-Delmotte et al., 2005). At Summit, the model simulates no change in $\delta^{18} \mathrm{O}_{\text {prec }}$, but $1.5^{\circ} \mathrm{C}$ cooler temperatures in the early Holocene (Fig. 5). This simulated cooling is consistent with other proxy evidence from the coast of Greenland that suggests cooler temperatures in the early Holocene (Kelly et al., 2008). This complexity in the Greenland $\delta^{18} \mathrm{O}_{\text {prec }}$ signal may induce large magnitude biases in Greenland ice core $\delta^{18} \mathrm{O}_{\text {prec }}$ - SAT records (Charles et al., 1995).

Deuterium excess changes are more complicated. The 1 kya through 6 kya time slices have only small or negligible changes over Greenland, and at 9 kya there are small changes of both sign. In Antarctica, deuterium excess is about $1 \%$ less over much of the continent by $9 \mathrm{~K}$, consistent with ice core evidence (Vimeux et al., 2001). As in Figs. 2 and 3, EH sea surface temperatures are largely (annual mean) cooler around Greenland, particularly in winter, due to lower NADW production. This region, particularly at $9 \mathrm{~K}$ represents the bulk of the original source of precipitation for Greenland (due to "blocking" from the remnant Laurentide of the Pacific source). Neither cooling, nor general changes in source region, appears to translate into a consistent change in deuterium excess over Greenland. Previous studies have also noted a lack of correlation between source region changes and deuterium excess changes (Kavanaugh and Cuffey, 2002). However, it should be noted that very little is known about mean changes to ocean water deuterium (even less than $\delta^{18} \mathrm{O}_{\mathrm{sw}}$ ) at various time slices through the deglacial. Further, deuterium excess is the most sensitive of all the modeled water isotopes to parameterization and kinetic effects, and thus the 9kya results should be viewed cautiously. 

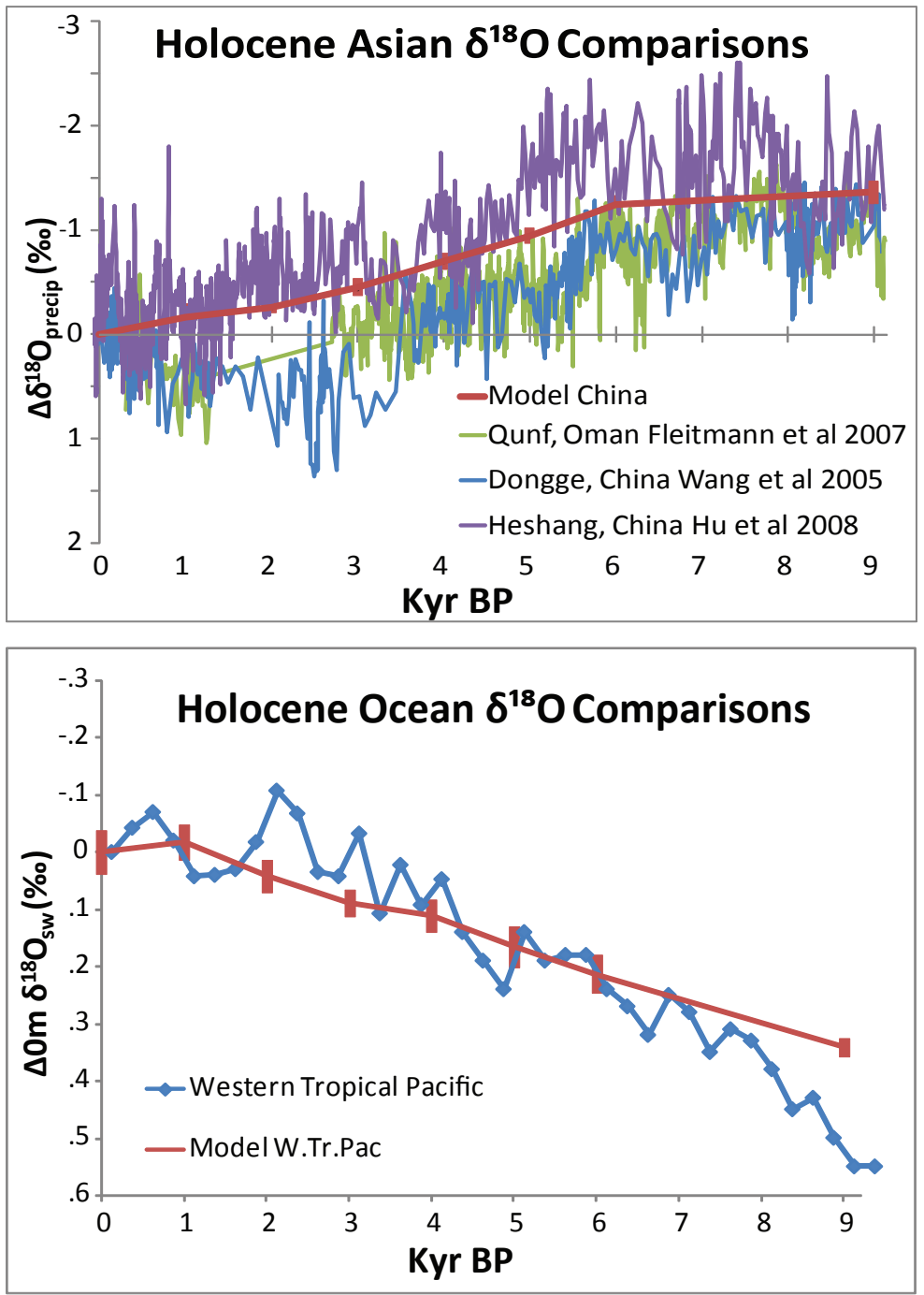

Fig. 6. (Upper) Annually averaged simulated $\delta^{18} \mathrm{O}_{\mathrm{pr}}$ changes over China (44 grid points) with $1 \sigma$ variability for decadal average about the model 100-year mean compared to speleothem $\delta^{18} \mathrm{O}$ from Oman (Fleitmann et al., 2007), Dongge, China (Wang et al., 2005), and Heshang, China (Hu et al., 2008). (Lower) Annually averaged simulated surface $\delta^{18} \mathrm{O}_{\mathrm{sw}}$ changes with $1 \sigma$ variability for decadal average about the model 100-year mean for the Western Tropical Pacific compared to measured (Stott et al., 2004). Values reported are normalized to modern. Ice volume changes have not been taken into account.

Shifts in precipitation related to movement of the ITCZ over the tropical oceans yields negative northern and positive southern $\delta^{18} \mathrm{O}_{\text {prec }}$ anomalies. Modeled changes in $\delta^{18} \mathrm{O}_{\text {prec }}$ of southern Eurasia closely resemble changes inferred from Asian speleothem $\delta^{18} \mathrm{O}$ records at millennial timescales (Fig. 6). The modeled tropical $\delta^{18} \mathrm{O}_{\text {prec }}$ changes do not, however, follow precipitation changes directly; notably, from West Africa through Northeast Asia, $\delta^{18} \mathrm{O}_{\text {prec }}$ is depleted, despite small and oppositely signed precipitation changes (Fig. 2). Nor are the $\delta^{18} \mathrm{O}_{\text {prec }}$ anomalies simply scalable to the magnitude of the local precipitation changes.

Closer examination of the simulated changes over China show no correlation between local precipitation and $\delta^{18} \mathrm{O}_{\text {prec }}$ over these timescales; however, there is a strong correlation between $\delta^{18} \mathrm{O}_{\text {prec }}$ and water vapor transport onto China from the Pacific (Fig. 7). In India, $\delta^{18} \mathrm{O}_{\text {prec }}$ changes are associated with not only water vapor transport changes onto land, but also precipitation changes (Fig. 7). This relationship suggests that millennial $\delta^{18} \mathrm{O}_{\text {prec }}$ changes inferred from tropical interior Asian $\delta^{18} \mathrm{O}$ records from speleothems are recording alterations in water vapor export out of the tropics, and not local changes in precipitation as might be inferred from present day analogs. In coastal regions, observed (GNIP/IAEA) tropical Asian $\delta^{18} \mathrm{O}$ records do correlate with local rainfall changes, but these changes are also highly correlated with the landward transport of water vapor from the oceans (Rozanski et al., 1993). Intensification of landward water vapor transport in the past simulations 


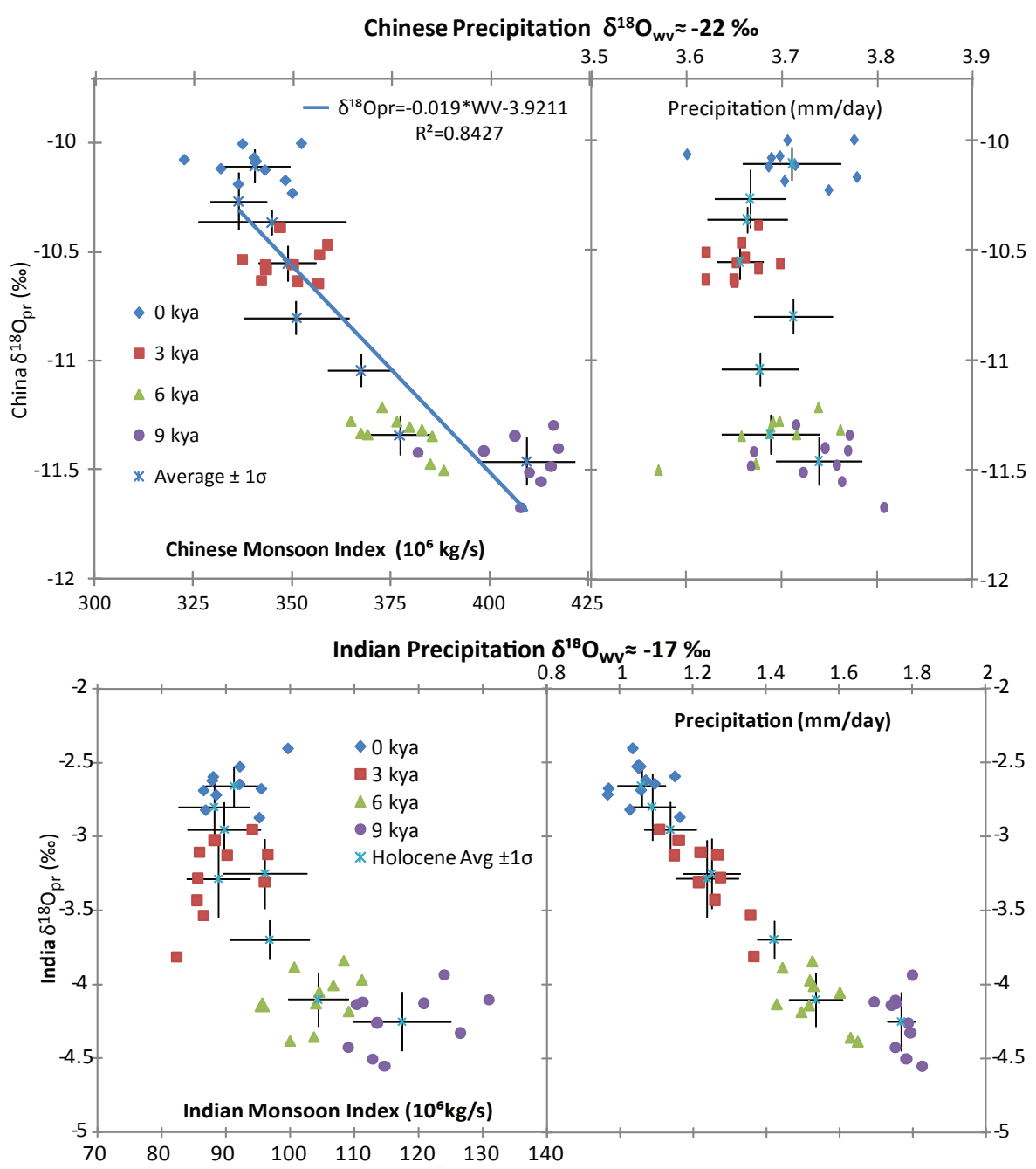

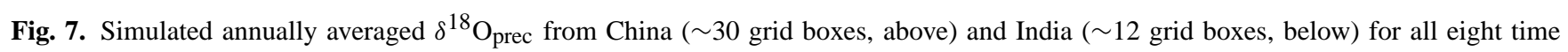
slices ( $1 \sigma$ variation in the decadal mean, black bars, about the century average, blue asterisk) are plotted (left) against a monsoon index onto land water vapor transport from the Indian or Pacific oceans - and (right) against precipitation (mm/day) averaged for the same region in China (above) and India (below). The monsoon index here is defined as the integrated JJA water vapor transport across the Chinese (above) and Indian (below) land-sea margin. Individual decadal averages appear for the 0 kya (blue diamonds), 3 kya (red squares), 6 kya (green triangles), and $9 \mathrm{kya}$ (purple circles) cases. "Monsoon" and $\delta^{18} \mathrm{O}_{\text {prec }}$ are inversely related, with greater water vapor transport onto land associated with more depleted rainfall on land in both, while local Chinese precipitation and $\delta^{18} \mathrm{O}_{\text {prec }}$ are uncorrelated, and Indian precipitation and $\delta^{18} \mathrm{O}_{\text {prec }}$ are correlated.

compared to modern is likely related to the enhanced boreal seasonality induced by orbital changes. Calcification temperature may be a confounding factor in some of the cave records $\left(-1 \%\right.$ o $\delta^{18} O$ per $\left.+5^{\circ} \mathrm{C}\right)$ where cave temperature is not constant, though this temperature variability will generally be significantly smaller than that of surface air temperature (Wang et al., 2008).

Associated with this shift in water export to the land are changes in the hydrological balance in related ocean regions. In the mid to early Holocene, simulated salinity and $\delta^{18} \mathrm{O}_{\mathrm{sw}}$ are lower in the Atlantic, particularly tropical to southern sub-tropical by $\sim 0.5 \mathrm{psu}$ and $\sim 0.2 \%$. Indian Ocean salinities and $\delta^{18} \mathrm{O}_{\mathrm{sw}}$ decrease as well, by a slightly larger magnitude. Western tropical Pacific salinities and $\delta^{18} \mathrm{O}_{\mathrm{sw}}$ increase by up to $\sim 0.6 \mathrm{psu}$ and $0.3 \%$, respectively. The modern depletion (.25\%o at the Mid-Holocene) of water isotopes in the Western Tropical Pacific matches well with paleosalinity reconstructions (Fig. 6 and Oppo et al., 2007). Rainfall over this area is generally enriched; $\delta^{18} \mathrm{O}_{\mathrm{sw}}$ and $\delta^{18} \mathrm{O}_{\text {prec }}$ changes over oceans tend to be correlated.

The salinity (and $\delta^{18} \mathrm{O}_{\mathrm{sw}}$ contrast) between the Western Tropical Atlantic and the eastern Tropical Pacific was less in the early Holocene owing mainly to decreased water vapor transport across the Isthmus of Panama. This modeled 

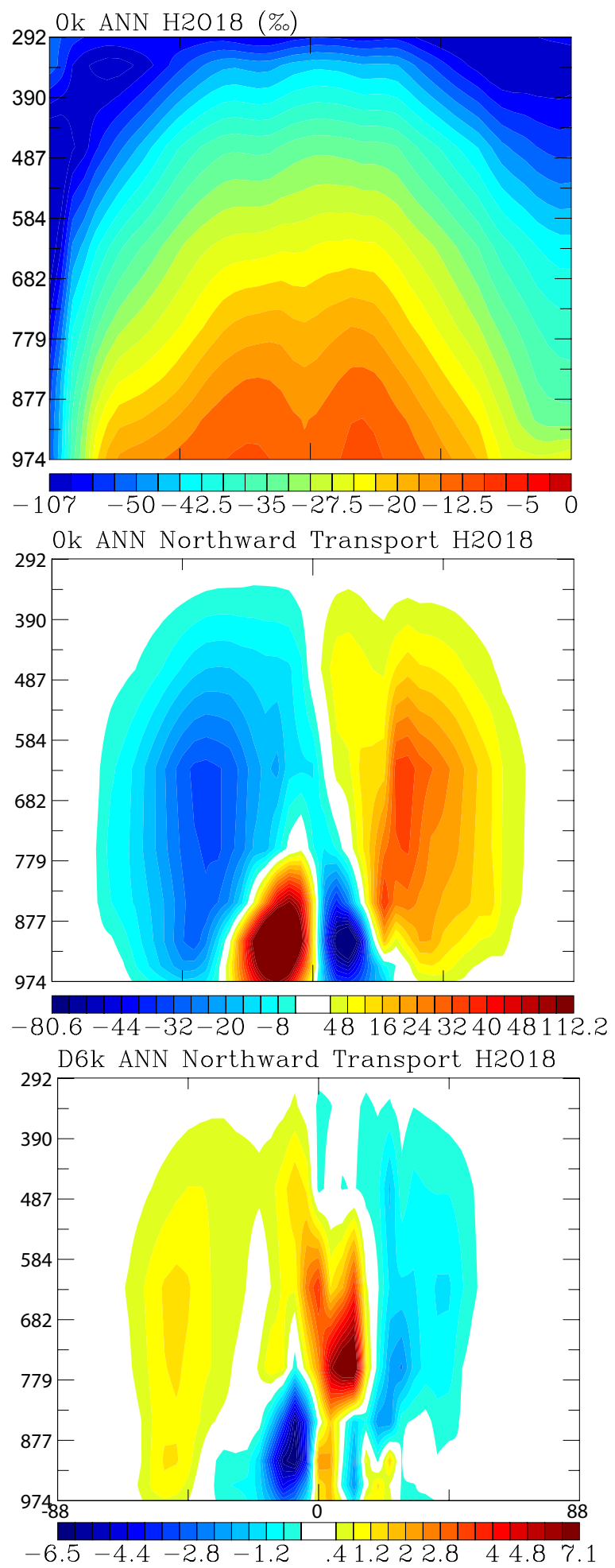

Fig. 8. Zonally averaged $\delta^{18} \mathrm{O}_{\text {prec }}(\%$ ) versus height (mbar) in the preindustrial and the anomaly in the mid-Holocene. Zonally averaged northward ${ }^{18} \mathrm{O}\left(10^{7} \mathrm{~kg} / \mathrm{s}\right)$ transport in the preindustrial and the anomaly in the mid-Holocene. trend is at odds with a recent paleoclimate reconstruction (i.e. Schmidt et al., 2004). Perhaps this is due to a lack of sufficiently high resolution data for comparisons, or the model simulations could be incorrect owing to overly coarse topography over Panama, which might compromise the sensitivity of the inter-basin transport. Further work on this issue is clearly warranted.

\subsection{Water vapor transport changes}

The tropical hydrologic cycle is closed to first order; i.e. the vast majority of water evaporated in the tropics, precipitates over the tropics (Hoffmann, 2003). In all of our simulations, the tropical water vapor recycling is indicated by the two near surface equator ward cells (Fig. 8b). Water vapor that does escape from the tropics does so in the mid troposphere $(\sim 800 \mathrm{mb})$. The isotopic composition of water vapor exiting the tropics is $-15 \%$ to $-20 \%$ ooth in these simulations and inferred from observations (Craig and Gordon, 1965; Lee, J., personal communication). The simulated average isotopic composition of this export flux changes very little over the course of the Holocene. There is a minor complication for stratospheric water vapor, owing to alterations in atmospheric methane concentration (a source of depleted $\left.\delta^{18} \mathrm{O}\right)$.

The simulated fluxes of water vapor, however, change dramatically over the course of the Holocene (Fig. 8c), with the export out of the tropics over the oceans decreasing over the Western Pacific by $\sim 12 \%$ in the mid-Holocene. Over land, enhanced boreal seasonality causes an increase in landsea temperature contrasts, and tropical water vapor transport onto land was thus greater during the mid-Holocene than today. Within the tropics, there is a northward migration of the ITCZ of $\sim 10-15^{\circ}$. This enhances water vapor transport onto West Africa and in Asia; e.g. flux onto China increases by $20 \%$, onto West India increases by $29 \%$; East Indian transport increases by $20 \%$ (Fig. 7).

Changes in northward water vapor transport (Fig. 8) imply changes in northward latent heat flux. Total atmospheric heat flux is a combination of this field and transport of dry static energy, and in these simulations, the magnitudes of changes in the two are similar (though regionally varying). Because of this fundamental link between atmospheric heat transport and water vapor flux, changes in tropical $\delta^{18} \mathrm{O}_{\text {precip }}$ for the Holocene might also be thought of as an indicator of changes in tropical atmospheric heat transports, with a greater export of tropical latent heat associated with a greater export of depleted $(-15$ to $-20 \%$ ) tropical water vapor. 


\subsection{Ocean circulation changes}

Exchange (surface through mixed layer depth) between the Labrador Sea and the North Atlantic was diminished by $1 / 3$ in the mid-Holocene simulations. In the early Holocene, the remaining fluxes out of the Labrador Sea into the North Atlantic were fresher and depleted by $2 \%$ on average, and the mixed layer in the Northwestern Atlantic was much shallower.

Transport of saltier surface waters from the Indian Ocean $\left(0.33 \delta^{18} \mathrm{O}_{\mathrm{sw}}\right)$ into the Atlantic was diminished by $25 \%$, while transport of tropical Pacific waters into the Indian Ocean was decreased by $13 \%$ in the early Holocene compared to the pre-Industrial. Advection from the Eastern to the Western Tropical Pacific increased by 5\%, with the $\delta^{18} \mathrm{O}_{\mathrm{sw}}$ enriched by $0.1 \%$.

Overall, the alterations in ocean circulation work to salinify the Pacific Ocean, and freshen the Atlantic (Fig. 4). The tropical western Pacific is 0.27 psu saltier and $0.1 \%$ enriched in $\delta^{18} \mathrm{O}_{\text {sw }}$. The tropical eastern Pacific has smaller changes of a similar sign, while the Atlantic is $0.16 \mathrm{psu}$ fresher and $0.1 \%$ o depleted in $\delta^{18} \mathrm{O}_{\mathrm{sw}}$.

These changes lead to enhanced intermediate water formation in the North Pacific, which yields a positive feedback to Northern Hemisphere warming (created by the enhanced boreal insolation), and a means for regionally warmer temperatures in the North Pacific region to persist through boreal winter.

In the pre-Industrial (control) simulation, there is a northward flux through the Bering Strait, though the simulated flux is significantly less (only 10\%) than that observed. In all of the other Holocene simulations, this flux reverses direction; by the early Holocene, this reversed flux has grown to 3 times the magnitude of that in the PI, and serves as a means to export freshwater out of the North Atlantic Ocean (via the Arctic). This reversal is likely driven by sea ice changes that are related to decreases in sea level pressure of $\sim 2 \mathrm{mb}$ and to a lesser extent by the surface freshwater balance $(\mathrm{P}-\mathrm{E}+\mathrm{R})$ increasing by $8 \%$. Surface and intermediate depth densities were greater in the Arctic, with the contrast of surface to deep water densities slightly reduced. A 9 kya sensitivity study where the Bering Strait was closed resulted in a shutdown of NADW since the additional freshwater fluxes from the melting of the LIS "pooled" in the North Atlantic. Note that the Bering Strait likely opened several thousand years prior to 9 kya and so that experiment is not intended to be directly comparable to observations. This result is however suggestive of a means for the termination of the Younger Dryas, but follow-up work is required to quantify its likelihood.

\section{Isotope record comparisons}

Seawater oxygen isotopes in the modern simulation compares favorably with observations (LeGrande and Schmidt, 2006), though the model tends to excessively smooth zonal asymmetries. Further, the model $\delta^{18} \mathrm{O}_{\text {prec }}$ does not attain the maximum depletion in Vostok Summit as observed (Schmidt et al., 2005); this may be related to model difficulties in simulating steep topography and extreme cold temperatures there. Atmospheric water vapor at the emission level in the atmosphere is similar to that observed from the TES (tropospheric emission spectrometer) instrument on the Aura spacecraft, though the seasonal cycle differs in sign (Jeonghoon Lee, personal communication).

The ModelE Holocene simulations can be quantitatively compared to relevant $\delta^{18} \mathrm{O}$ records. Broad trends of increased $\delta^{18} \mathrm{O}_{\text {prec }}$ from the early to late Holocene from Asian speleothem records is well reproduced (Fleitmann et al., 2003; Hu et al., 2008; Wang et al., 2005). Further, $0.2 \%$ o to $0.3 \%$ mid-Holocene increases in Western Tropical Pacific $\delta^{18} \mathrm{O}_{\mathrm{sw}}$ are also simulated well in the model (Fig. 6; Stott et al., 2004). All Holocene simulations have $\delta^{18} \mathrm{O}_{\text {prec }}$ at Summit, Greenland of $-34.7 \%$ to $-35 \%$, within the observed range over the Holocene, $-34.1 \%$ o to $-36 \%$ (Masson-Delmotte et al., 2005). Simulated early Holocene oxygen isotopes are similar (with a correlation, $r^{2}$, of 0.83 ) to observed in ice cores and marine sediment cores (Carlson et al., 2008). Simulated tropical Pacific seawater oxygen isotopes are, similar to observed, enriched by $\sim 0.3 \%$, as well (Oppo et al., 2007).

Changes in simulated salinity are significantly less than implied by modern co-variability $\delta^{18} \mathrm{O}_{\mathrm{sw}}$ and salinity (e.g. LeGrande and Schmidt, 2006) in the tropical western Atlantic, Caribbean, and Western Tropical Pacific. Data inferences of $\sim 1.5$ psu salinity changes through the Holocene (Stott et al., 2004), derived from $\delta^{18} \mathrm{O}_{\mathrm{sw}}$ applying the modern $0.15-0.25 \%$ o per psu, spatial relationship, could be off by $200-300 \%$; i.e. the salinity changes were likely smaller, $(\sim 0.5 \mathrm{psu})$. Simulated western Tropical Pacific changes in EH salinity, including ice volume effects, are $\sim 0.3 \mathrm{psu}$. Similarly, the western tropical Atlantic and Caribbean also show more modest salinity changes than that implied by applying the modern spatial slope to the past $\delta^{18} \mathrm{O}_{\mathrm{sw}}$ variability. This feature highlights the importance of distinguishing spatial from temporal slopes. The primary mechanism controlling shallow tropical spatial slopes - the first order complete recycling of water vapor within only the tropics - is not necessarily the same as that acting to control millennial scale variability. At this temporal scale, inter-ocean basin exchange of water is important. This feature will be explored in future research. For the time being, however, more work is required to understand a means to quantitatively interpret $\delta^{18} \mathrm{O}_{\mathrm{sw}}$ signals as paleosalinity. 
It should be noted here, however, that while some isotopic proxies can be directly compared to model output (i.e. ice core $\delta^{18} \mathrm{O}$ ) some proxy measurements require a more sophisticated forward modeling approach. For instance, calcite $\delta^{18} \mathrm{O}$ also has a temperature dependent fractionation (Epstein et al., 1953). This dependence is usually accounted for in marine records, but not in speleothem records (temperature variability in caves is thought to be minor compared to the impact of cave water $\delta^{18} \mathrm{O}$ ). Terrestrial records of $\delta^{18} \mathrm{O}$ are often complicated since re-evaporation or variable residence times in the ground can alter the $\delta^{18} \mathrm{O}$ from that originally in the precipitation. More sophisticated treatments of these processes are under development.

\section{Discussion}

Many of the existing studies using ModelE-R have focused on sensitivity of the model to future projected greenhouse gas changes (e.g. Hansen et al., 2005; Hansen et al., 2007). These results show that in a warmer (greenhouse driven) world, atmospheric circulation changes such that northward latent heat transport increases and sensible heat decreases trends that follow from the changes in temperature and water mass in the atmosphere. In our Mid- and Early Holocene simulations, the global temperature is slightly lower - MH greenhouse gas decreases, correspond to a $-0.34^{\circ} \mathrm{C}$ SAT, consistent with the GISS ModelE climate sensitivity of $\sim 2.7^{\circ} \mathrm{C} / 2 \times \mathrm{CO}_{2}$, which would correspond to a temperature change of $-0.38^{\circ} \mathrm{C} \mathrm{SAT}$, but northern hemisphere temperatures are increased (as a result of orbital changes). The early Holocene simulation has an additional complication of cooler eastern North-eastern American and Northwestern Atlantic temperatures (as a result of the remnant Laurentide Ice Sheet). Water vapor content increases in the northern hemisphere but decreases in the southern hemisphere (owing to slightly lower insolation at mid-latitudes and reduced greenhouse gases). The zonal mean changes in heat transport show a decrease in latent heat transport in the northern midlatitudes. These changes demonstrate a very complicated picture where enhanced seasonality drives large changes in land-sea temperature contrast, and this change dominates changes to water vapor and latent heat transport.

Water isotope fields show distinctive "fingerprints" of climate changes through the Holocene. In the atmosphere, these changes are very similar to latent heat changes. Latent heat transport changes dominate the total atmospheric heat transport changes, and illuminate the fundamental link between water vapor, temperature, and $\delta^{18} \mathrm{O}$, even in continental tropical settings. The correlation between $\delta^{18} \mathrm{O}_{\text {prec }}$ and precipitation in these locations breaks down since changes in water vapor transport dominate the final $\delta^{18} \mathrm{O}_{\text {prec }}$ signal. Terrestrial $\delta^{18} \mathrm{O}$ changes in water isotopes represent alterations to the water vapor flux onto land. Changes in temperature and $\delta^{18} \mathrm{O}_{\text {prec }}$ at high latitudes are both related to changes in water vapor flux (thus often correlated), but the patterns of change in the two are not always identical. Thus situations arise such as in the early Holocene where changes in temperature at Summit, Greenland are not captured in the $\delta^{18} \mathrm{O}_{\text {prec }}$ signal - water vapor flux changes from the Pacific complicate the signal.

Large changes in atmospheric water vapor transport have important consequences for seawater isotopes as well. Alterations in inter-basin exchange, land-sea amounts of precipitation, and tropical export of water vapor all have impacts on the hydrologic cycle and affect the marine $\delta^{18} \mathrm{O}$ records in addition to their terrestrial counterparts. Past reconstructions of $\delta^{18} \mathrm{O}_{\mathrm{sw}}$ thus can provide insight into atmospheric processes. The consequence, however, of this atmospheric connection is that simple links to other freshwater tracers is complicated. For instance, modern $\delta^{18} \mathrm{O}_{\mathrm{sw}}$ to salinity calibrations to determine past salinity given a $\delta^{18} \mathrm{O}_{\mathrm{sw}}$ record do not currently include corrections due to atmospheric circulation changes. This study suggests that modern $\delta^{18} \mathrm{O}_{\mathrm{sw}}$ to salinity relationships yield a qualitative calibration, which may be improved by expanding the terms (that $\delta^{18} \mathrm{O}_{\text {sw }}$ depends on) to include more of the hydrologic cycle. These large changes in water vapor transport imply large changes in the salinity and $\delta^{18} \mathrm{O}_{\text {sw }}$ end members, suggesting a means for improved interpretations of $\delta^{18} \mathrm{O}_{\mathrm{sw}}$. The pairing of oxygen isotope records with other proxy records for salinity may reduce uncertainty in salinity reconstructions as well as provide more insight into changes of the hydrologic cycle in general (Rohling, 2007).

We used eight time slices across the Holocene in order to provide greater confidence in $\delta^{18} \mathrm{O}$ to climate inversions (8 data points). However, the majority of the features present in the mid-Holocene case are similar to those seen in the 1 kya through 5 kya cases, with primarily the magnitude of anomalies changing. The Early Holocene case has the added complication of changes in ice sheets, and its patterns of climate change differ from those in the 6 kya case. From this result, it seems that transient, or high temporal resolution time slice through periods of ice sheet change are necessary, while transient/high temporal resolution time slice simulations of interstadials will be less useful, unless additional short term forcing elements (such as solar irradiance) become sufficiently quantified to affect the simulations in ways not considered here.

\section{Conclusions}

Forward modeling of proxy climate tracers is essential in understanding the variability in the proxy climate archives. Oxygen isotopes record changes in the hydrologic cycle, meaning that complexities including temperature, precipitation, initial source composition, pathways to deposition, and mixing along the route always play a role in determining the final composition. Our Holocene simulations suggest that 
during periods of change in the orography of North America (growth and retreat of the Laurentide Ice Sheet, in particular), forward modeling may be very helpful in determining the temperature signal in the Greenland ice core $\delta^{18} \mathrm{O}_{\text {prec }}$ records, since changes in precipitation source (in addition to temperature) play an important role to the variability there (Charles et al., 1994). In monsoonal regions, such as south Asia, variability in water vapor transport on land again is important to controlling $\delta^{18} \mathrm{O}_{\text {prec }}$ variability, contrary to some interpretations of this variability in terms of local precipitation amount (which is a poor approximation in these simulations at least). Models have an important role in elucidating which components of change in the hydrologic cycle are most responsible for variability at different timescales, and thus they provide a means for improved interpretations of proxy climate archives.

Regional to hemispheric wide scale changes in water vapor transport are the component that seem to be the major complicating factor that is rarely addressed in interpretations of individual time series of $\delta^{18} \mathrm{O}$ from proxy records. This component is the aspect for which interpretations can be most greatly improved through the forward modeling of $\delta^{18} \mathrm{O}$ tracers.

The GISS model does capture the major features of Northern Hemisphere warming during the mid-Holocene. In the Early Holocene, Northern Hemisphere climate is consistent with the known rates of retreat of the North American ice sheets, and climate of the time (Carlson et al., 2008). Similarly, the GISS model matches tropical ocean (Oppo et al., 2007) and land variability, particularly Asian speleothems, in the mid-Holocene well. This suggests that the model has appropriately sized responses to orbital changes and to small greenhouse gas changes. However, increases in Sahel rainfall and sea ice reductions from the mid to early Holocene are too small (Wohlfahrt et al., 2008). Overall, the GISS model reasonably simulates climate over the Holocene (compared to the proxy records), and the variability in these tracers provides a way to assess the skill of the model over the Holocene and perhaps improve confidence in elements of the projections into the future.

Acknowledgements. We would like to thank NASA GISS for institutional support. ANL was supported by NSF ATM 07-53868.

Edited by: H. Renssen

\section{References}

Alley, R. B., Mayewski, P. A., Sowers, T., Stuiver, M., Taylor, K. C., and Clark, P. U.: Holocene climatic instability: A prominent, widespread event 8200 yr ago, Geology, 25(6), 483-486, 1997.

Araguas-Araguas, L., Froehlich, K., and Rozanski, K.: Deuterium and oxygen-18 isotope composition of precipitation and atmospheric moisture, Hydrol. Process., 14(8), 1341-1355, 2000.
Berger, A. and Loutre, M. F.: Insolation Values for the Climate of the Last 10000000 Years, Quaternary Sci. Rev., 10(4), 297-317, 1991.

Braconnot, P., Otto-Bliesner, B., Harrison, S., Joussaume, S., Peterchmitt, J.-Y., Abe-Ouchi, A., Crucifix, M., Driesschaert, E., Fichefet, Th., Hewitt, C. D., Kageyama, M., Kitoh, A., Loutre, M.-F., Marti, O., Merkel, U., Ramstein, G., Valdes, P., Weber, L., Yu, Y., and Zhao, Y.: Results of PMIP2 coupled simulations of the Mid-Holocene and Last Glacial Maximum - Part 2: feedbacks with emphasis on the location of the ITCZ and mid- and high latitudes heat budget, Clim. Past, 3, 279-296, 2007, http://www.clim-past.net/3/279/2007/.

Brook, E. J., Harder, S., Severinghaus, J., Steig, E. J., and Sucher, C. M.: On the origin and timing of rapid changes in atmospheric methane during the last glacial period, Global Biogeochem. Cy., 14(2), 559-572, 2000.

Carlson, A. E., Clark, P. U., Raisbeck, G. M., and Brook, E. J.: Rapid Holocene deglaciation of the Labrador sector of the Laurentide Ice Sheet, J. Climate, 20(20), 5126-5133, 2007.

Carlson, A. E., LeGrande, A. N., Oppo, D. W., Came, R. E., Schmidt, G. A., Anslow, F. S., Licciardi, J. M., and Obbink, E. A.: Rapid early Holocene deglaciation of the Laurentide ice sheet, Nat. Geosci., 1(9), 620-624, 2008.

Charles, C. D., Rind, D., Jouzel, J., Koster, R. D., and Fairbanks, R. G.: Glacial-Interglacial Changes in Moisture Sources for Greenland - Influences on the Ice Core Record of Climate, Science, 263(5146), 508-511, 1994.

Charles, C. D., Rind, D., Jouzel, J., Koster, R. D., and Fairbanks, R. G.: Seasonal Precipitation Timing and Ice Core Records, Science, 269(5221), 247-248, 1995.

Craig, H. and Gordon, L. I.: Deuterium and Oxygen 18 Variations in the Ocean and the Marine Atmosphere, Pisa, Italy, 1965.

Cuffey, K. M., Clow, G. D., Alley, R. B., Stuiver, M., Waddington, E. D., and Saltus, R. W.: Large Arctic Temperature-Change at the Wisconsin-Holocene Glacial Transition, Science, 270(5235), 455-458, 1995.

Dansgaard, W.: Stable isotopes in precipitation, Tellus, 16, 436468, 1964.

Epstein, S., Buchsbaum, R., Lowenstam, A., and Urey, H. C.: Revised carbonate-water isotopic temperature scale, Geol. Soc. Am. Bull., 64, 1315-1325, 1953.

Fairbanks, R. G.: A 17000 -year glacio-eustatic sea level record: influence of glacial melting rates on the Younger Dryas event and deep-ocean circulation, Nature, 342, 637-642, 1989.

Fleitmann, D., Burns, S. J., Mangini, A., Mudelsee, M., Kramers, J., Villa, I., Neff, U., Al-Subbary, A. A., Buettner, A., Hippler, D., and Matter, A.: Holocene ITCZ and Indian monsoon dynamics recorded in stalagmites from Oman and Yemen (Socotra), Quaternary Sci. Rev., 26(1-2), 170-188, 2007.

Fleitmann, D., Burns, S. J., Mudelsee, M., Neff, U., Kramers, J., Mangini, A., and Matter, A.: Holocene forcing of the Indian monsoon recorded in a stalagmite from Southern Oman, Science, 300(5626), 1737-1739, 2003.

Hansen, J., Nazarenko, L., Ruedy, R., Sato, M., Willis, J., Del Genio, A., Koch, D., Lacis, A., Lo, K., Menon, S., Novakov, T., Perlwitz, J., Russell, G., Schmidt, G. A., and Tausnev, N.: Earth's energy imbalance: Confirmation and implications, Science, 308(5727), 1431-1435, 2005.

Hansen, J., Sato, M., Ruedy, R., Kharecha, P., Lacis, A., Miller, 
R., Nazarenko, L., Lo, K., Schmidt, G. A., Russell, G., Aleinov, I., Bauer, S., Baum, E., Cairns, B., Canuto, V., Chandler, M., Cheng, Y., Cohen, A., Del Genio, A., Faluvegi, G., Fleming, E., Friend, A., Hall, T., Jackman, C., Jonas, J., Kelley, M., Kiang, N. Y., Koch, D., Labow, G., Lerner, J., Menon, S., Novakov, T., Oinas, V., Perlwitz, J., Rind, D., Romanou, A., Schmunk, R., Shindell, D., Stone, P., Sun, S., Streets, D., Tausnev, N., Thresher, D., Unger, N., Yao, M., and Zhang, S.: Climate simulations for 1880-2003 with GISS modelE, Clim. Dynam., 29(7-8), 661-696, 2007.

Haug, G. H., Hughen, K. A., Sigman, D. M., Peterson, L. C., and Röhl, U.: Southward migration of the intertropical convergence zone through the Holocene, Science, 293(5533), 13041308, 2001.

Hillaire-Marcel, C., de Vernal, A., Bilodeau, G., and Weaver, A. J.: Absence of deep-water formation in the Labrador Sea during the last interglacial period, Nature, 410(6832), 1073-1077, doi:10.1038/35074059, 2001.

Hoffmann, G.: Taking the pulse of the tropical water cycle, Science, 301(5634), 776-777, 2003.

Hu, C., Henderson, G. A., Huang, ., Xie, S., Sun, Y., and Johnson, R. G.: Quantification of Holocene Asian monsoon rainfall from spatially separated cave records, Earth Planet. Sci. Lett., 226(34), 221-232, 2008.

Indermuhle, A., Stocker, T. F. , Joos, F., Fischer, H., Smith, H. J., Wahlen, M., Deck, B., Mastroianni, D., Tschumi, J., Blunier, T., Meyer, R., and Stauffer, B.: Holocene carbon-cycle dynamics based on $\mathrm{CO}_{2}$ trapped in ice at Taylor Dome, Antarctica, Nature, 398(6723), 121-126, 1999.

Jouzel, J., Masson-Delmotte, V., Cattani, O., Dreyfus, G., Falourd, S., Hoffmann, G., Minster, B., Nouet, J., Barnola, J. M., Chappellaz, ., Fischer, H., Gallet, J. C., Johnsen, S., Leuenberger, M., Loulergue, L., Luethi, D., Oerter, H., Parrenin, F., Raisbeck, G., Raynaud, D., Schilt, A., Schwander, J., Selmo, E., Souchez, R., Spahni, R., Stauffer, B., Steffensen, J. P., Stenni, B., Stocker, T. F., Tison, J. L., Werner, ., and Wolff, E. W.: Orbital and millennial Antarctic climate variability over the past 800000 years, Science, 317(5839), 793-796, 2007.

Jouzel, J., Vimeux, F., Caillon, N., Delaygue, G., Hoffmann, G., Masson-Delmotte, V., and Parrenin, F.: Magnitude of isotope/temperature scaling for interpretation of central Antarctic ice cores, J. Geophys. Res.-Atmos., 108, D124361, doi:10.1029/2002JD002677, 2003.

Kavanaugh, J. L. and Cuffey, K. M.: Generalized view of sourceregion effects on delta $\mathrm{D}$ and deuterium excess of ice-sheet precipitation, Ann. Glaciol., 35(35), 111-117, 2002.

Kelly, M. A., Lowell, T. V., Hall, B. L., Schaefer, J. M., Finkel, R. C., Goehring, B. M., Alley, R. B., and Denton, G. H.: A Be10 chronology of lateglacial and Holocene mountain glaciation in the Scoresby Sund region, east Greenland: implications for seasonality during lateglacial time, Quaternary Sci. Rev., 27(2526), 2273-2282, 2008.

LeGrande, A. N. and Schmidt, G. A.: Global gridded dataset of the oxygen isotopic composition in seawater, Geophys. Res. Lett., 33(12), L12604, doi:10.1029/2006GL026011, 2006.

LeGrande, A. N. and Schmidt, G. A.: Ensemble, water isotope-enabled, coupled general circulation modeling insights into the $8.2 \mathrm{ka}$ event, Paleoceanography, 23(3), PA3207, doi:10.1029/2008PA001610, 2008.
Licciardi, J. M., Clark, P. U., Jenson, J. W., and Macayeal, D. R.: Deglaciation of a soft-bedded Laurentide Ice Sheet, Quaternary Sci. Rev., 17(4-5), 427-448, 1998.

Maher, B. A.: Holocene variability of the East Asian summer monsoon from Chinese cave records: a re-assessment, Holocene, 18(6), 861-866, 2008.

Masson-Delmotte, V., Hou, S., Ekaykin, A., Jouzel, J., Aristarain, A., Bernardo, R. T., Bromwich, D., Cattani, O., Delmotte, M., Falourd, S., Frezzotti, M., Gallee, H., Genoni, L., Isaksson, E., Landais, A., Helsen, M. M., Hoffmann, G., Lopez, ., Morgan, V., Motoyama, H., Noone, D., Oerter, H., Petit, J. R., Royer, A., Uemura, R., Schmidt, G. A., Schlosser, E., Simoes, J. C., Steig, E. J., Stenni, M. Stievenard, M. R. Van den Broeke, R. S. W. V. De Wal, W. J. V. de Berg, B., Vimeux, F., and White, J. W. C.: A review of Antarctic surface snow isotopic composition: Observations, atmospheric circulation, and isotopic modeling, J. Climate, 21(13), 3359-3387, 2008.

Masson-Delmotte, V., Kageyama, M., Braconnot, P., Charbit, S., Krinner, G., Ritz, C., Guilyardi, E., Jouzel, J., be-Ouchi, A., Crucifix, M., Gladstone, R. M., Hewitt, C. D., Kitoh, A., LeGrande, A. N., Marti, O., Merkel, U., Motoi, T., Ohgaito, R., OttoBliesner, B., Peltier, W. R., Ross, I., Valdes, P. J., Vettoretti, G., Weber, S. L., Wolk, F., and Yu, Y.: Past and future polar amplification of climate change: climate model intercomparisons and ice-core constraints, Clim. Dynam., 26(5), 513-529, 2006.

Masson-Delmotte, V., Landais, A., Stievenard, M., Cattani, O., Falourd, S., Jouzel, J., Johnsen, S. J., Jensen, D. D., Sveinsbjornsdottir, A., White, J. W. C., Popp, T., and Fischer, H.: Holocene climatic changes in Greenland: Different deuterium excess signals at Greenland Ice Core Project (GRIP) and NorthGRIP, J. Geophys. Res.-Atmos., 110(D14), D14102, doi:10.1029/2004JD005575, 2005.

McManus, J. F., Francois, R., Gherardi, J. M., Keigwin, L. D., and Brown-Leger, S.: Collapse and rapid resumption of Atlantic meridional circulation linked to deglacial climate changes, Nature, 428(6985), 834-837, 2004.

Oppo, D. W., Schmidt, G. A., and LeGrande, A. N.: Seawater isotope constraints on tropical hydrology during the Holocene, Geophys. Res. Lett., 34, L13701, doi:10.1029/2007GL030017, 2007.

Pearman, P. B., Randin, C. F., Broennimann, O., Vittoz, P., van der Knaap, W. O., Engler, R., Le Lay, G., Zimmermann, N. E., and Guisan, A.: Prediction of plant species distributions across six millennia, Ecol. Lett., 11(4), 357-369, 2008.

Renssen, H., Seppa, H., Heiri O., Roche, D. M., Goosse, H., and Fichefet, T.: The spatial and temporal complexity of the Holocene thermal maximum, Nat. Geosci., 2(6), 410-413, doi:10.1038/ngeo513, 2009.

Roden, J. S., Lin, G. G., and Ehleringer, J. R.: A mechanistic model for interpretation of hydrogen and oxygen isotope ratios in treering cellulose, Geochim. Cosmochim. Ac., 64(1), 21-35, 2000.

Rohling, E. J.: Progress in paleosalinity: Overview and presentation of a new approach, Paleoceanography, 22(3), PA3215, doi:10.1029/2007PA001437, 2007.

Rozanski, K., Araguas-Araguas, L., and Gonfiantini, R.: Isotopic patterns in modern global precipitation, American Geophysical Union, Washington, D.C., 78, 1993.

Schmidt, G. A.: Error analysis of paleosalinity calculations, Paleoceanography, 14(3), 422-429, 1999.

Schmidt, G. A., Hoffmann, G., Shindell, D. T., and Hu, Y. 
Y.: Modeling atmospheric stable water isotopes and the potential for constraining cloud processes and stratospheretroposphere water exchange, J. Geophys. Res.-Atmos., 110, D21, doi:10.1029/2005JD005790, 2005.

Schmidt, G. A., LeGrande, A. N., and Hoffmann, G.: Water isotope expressions of intrinsic and forced variability in a coupled ocean-atmosphere model, J. Geophys. Res.-Atmos., 112, D10103, doi:10.1029/2006JD007781, 2007.

Schmidt, G. A., Reudy, R., Hansen, J. E., Aleinov, I., Bell, N., Bauer, M., Bauer, S., Cairns, B., Canuto, V., Cheng, Y., Del Genio, A., Faluvegi, G., Friend, A. D., Hall, T. M., Hu, Y., Kelley, M., Kiang, N. Y., Koch, D., Lacis, A. A., Lerner, J., Lo, K. K., Miller, R. L., Nazarenko, L., Oinas, V., Perlwitz, J., Perlwitz, J., Rind, D., Romanou, A., Russell, G. L., Sato, M., Shindell, D. T., Stone, P. H., Sun, S., Tausnev, N., Thresher, D., and Yao, M.-Y.: Present day atmospheric simulations using GISS ModelE: Comparison to in-situ, satellite and reanalysis data, J. Climate, 19, 153-192, doi:10.1175/JCLI3612.1, 2006.

Schmidt, M. W., Spero, H. J., and Lea, D. W.: Links between salinity variation in the Caribbean and North Atlantic thermohaline circulation, Nature, 428(6979), 160-163, doi:10.1038/nature02346, 2004.

Sime, L. C., Tindall, J. C., Wolff, E. W., Connolley, W. M., and Valdes, P. J.: Antarctic isotopic thermometer during a $\mathrm{CO}_{2}$ forced warming event, J. Geophys. Res.-Atmos., 113, D24119, doi:10.1029/2008JD010395, 2008.

Sowers, T., Alley, R. B., and Jubenville, J.: Ice core records of atmospheric $\mathrm{N}_{2} \mathrm{O}$ covering the last 106000 years, Science, 301(5635), 945-948, 2003.

Stott, L., Cannariato, K., Thunell, R., Haug, G. H., Koutavas, A., and Lund, S.: Decline of surface temperature and salinity in the western tropical Pacific Ocean in the Holocene epoch, Nature, 431(7004), 56-59, doi:10.1038/nature02903, 2004.

Stroeve, J., Holland, M. M., Meier, W., Scambos, T., and Serreze,.: Arctic sea ice decline: Faster than forecast, Geophys. Res. Lett., 34(9), L09501, doi:10.1029/2007GL029703, 2007.

Thomas, E. R., Wolff, E. W., Mulvaney, R., Steffensen, J. P., Johnsen, S. J., Arrowsmith, C., White, J. W. C., Vaughn, B., and Popp, T.: The 8.2 ka event from Greenland ice cores, Quaternary Sci. Rev., 26(1-2), 70-81, 2007.

Treydte, K., Frank, D., Esper, J., Andreu, L., Bednarz, Z., Berninger, F., Boettger, T., D’Alessandro, C. M., Etien, N., Filot, M., Grabner, M., Guillemin, M. T., Gutierrez, E., Haupt, M., Helle, G., Hilasvuori, E., Jungner, H., Kalela-Brundin, M., Krapiec, M., Leuenberger, M., Loader, N. J., Masson-Delmotte, V.,
Pazdur, A., Pawelczyk, S., Pierre, M., Planells, O., Pukiene, R., Reynolds-Henne, C. E., Rinne, K. T., Saracino, A., Saurer, M., Sonninen, E., Stievenard, M., Switsur, V. R., Szczepanek, M., Szychowska-Krapiec, E., Todaro, L., Waterhouse, J. S., Weigl, M., and Schleser, G. H.: (2007), Signal strength and climate calibration of a European tree-ring isotope network, Geophys. Res. Lett., 34(24), L24302, doi:10.1029/2007GL031106, 2007.

Vimeux, F., Masson, V., Jouzel, J., Petit, J. R., Steig, E. J., Stievenard, ., Vaikmae, R., and White, J. W. C.: Holocene hydrological cycle changes in the Southern Hemisphere documented in East Antarctic deuterium excess records, Clim. Dynam., 17(7), 503513, 2001.

von Grafenstein, U., Erlenkeuser, H., Brauer, A., Jouzel, J., and Johnsen, S. J.: A mid-European decadal isotope-climate record from 15500 to 5000 years BP, Science, 284(5420), 1654-1657, 1999.

Wang, Y. J., Cheng, H., Edwards, R. L., An, Z. S., Wu, J. Y., Shen, C. C., and Dorale, J. A.: A high-resolution absolute-dated Late Pleistocene monsoon record from Hulu Cave, China, Science, 294(5550), 2345-2348, 2001.

Wang, Y. J., Cheng, H., Edwards, R. L., He, Y. Q., Kong, X. G., An, Z. S., Wu, J. Y., Kelly, M. J., Dykoski, C. A, and Li, X. D.: The Holocene Asian monsoon: Links to solar changes and North Atlantic climate, Science, 308(5723), 854857, doi:10.1126/science.1106296, 2005.

Wang, Y. J., Cheng, H., Edwards, R. L., Kong, X. G., Shao, X. H, Chen, S. T., Wu, J. Y., Jiang, X. Y., Wang, X. F., and An, Z. S.: Millennial- and orbital-scale changes in the East Asian monsoon over the past 224000 years, Nature, 451(7182), 10901093, 2008.

Wanner, H., Beer, J., Butikofer, J., Crowley, T. J., Cubasch, U., Fluckiger, J., Goosse, H., Grosjean, M., Joos, F., Kaplan, J. O., Kuttel, M., Muller, S. A., Prentice, I. C., Solomina, O., Stocker, T. F., Tarasov, P., Wagner, M., and Widmann, M.: Mid- to Late Holocene climate change: an overview, Quaternary Sci. Rev., 27(19-20), 1791-1828, 2008.

Werner, M., Mikolajewicz, U., Heimann, M. and Hoffmann, G.: Borehole versus isotope temperatures on Greenland: Seasonality does matter, Geophys. Res. Lett., 27(5), 723-726, 2000.

Wohlfahrt, J., Harrison, S. P., Braconnot, P., Hewitt, C. D., Kitoh, A., Mikolajewicz, U., Otto-Bliesner, B. L., and Weber, S. L.: Evaluation of coupled ocean-atmosphere simulations of the midHolocene using palaeovegetation data from the northern hemisphere extratropics, Clim. Dynam., 31(7-8), 871-890, 2008. 